УДК 378.1:379.85

DOI:

Любов Гончар, кандидат економічних наук, доиент кафедри обліку і аудиту ДВНЗ “Донбаський державний педагогічний університет”

\title{
СУТНІСНІ ХАРАКТЕРИСТИКИ ПРОЦЕСУ ФОРМУВАННЯ КУЛЬТУРИ ПРОФЕСІЙНОЇ ДІЯЛЬНОСТІ МАЙБУТНІХ МЕНЕДЖЕРІВ
}

У статті проводиться аналіз психолого-педагогічної літератури та досліджень науковиів, які вивчали сутнісні характеристики процесу формування культури професійної діяльності майбутніх менеджерів. Визначена актуальність досліджувальної проблеми, розкриваються сутнісні характеристики досліджуваних понять “професійна культура", “професійна культура майбутнього менеджера”, виявлена орієнтація психолого-педагогічної науки на користь пошуку нових иляхів організачї прочесу формування культури професійної діяльності майбутніх менеджерів в умовах закладів вищої освіти. Акиентується увага на важливості "Я-концепиї" майбутнього менеджера, щьо включає усвідомлення себе як професіонала, носія професійної культури, представника певної професії. Проаналізовано форми активної діяльності студентської молоді у формуванні культури професійної діяльності майбутніх менеджерів. Наведено перелік навчальних дисчиплін, що сприяють ефективному формуванню культури професійної діяльності майбутніх менеджерів.

Ключові слова: інновації; культура професійної діяльності; майбутні менеджери; професійна культура.

Jim. 6.

Lyubov Honchar, Ph.D.(Economical Sciences), Associate Professor of the Accounting and Auditing Department,

Donbass State Pedagogical University

\section{ESSENTIAL CHARACTERISTICS OF THE PROCESS OF FORMATION OF CULTURE OF PROFESSIONALACTIVITY OF FUTURE MANAGERS}

The article analyzes the psychological and pedagogical literature and researches of scientists who studied the essential characteristics of the process of forming the culture of professional activity of future managers. The relevance of the research problem is determined, the essential characteristics of the studied concepts: "professional culture", "professional culture of the future manager" are revealed, the orientation of psychological and pedagogical science in favor of finding new ways of organizing the process of forming the culture of professional activity of future managers in higher education institutions is revealed. An emphasis is placed on the importance of the "I-concept" of the future manager, which includes awareness of himself as a professional, a carrier of professional culture, a representative of a particular profession. The forms of active activity of student youth in forming the culture of professional activity of future managers are analyzed. The list of educational disciplines contributing to the effective formation of the culture of professional activity of future managers is given. Forms, methods, means of forming the culture of professional activity of future managers are revealed. The influence of educational innovations on the practice of professional training of managers, which look like a certain model of innovative educational process, which covers six stages, is revealed. The content and structure of the professional culture of the manager are revealed. Interactive forms of organization of educational process that also contribute to the effective formation of professional culture of future managers are outlined, namely: coaching-training, pedagogical design, business games, brain-rings, SWOT-analysis, cases, consultations, situational methods, development of animation activities, lines workshops, webinars, workshops, flash mobs, exhibitions, fairs, auctions, themed guest events, art projects, gala nights, tournaments, marathons, author studios, quests, and more. At the end of the article, conclusions are drawn and the prospects for further development of this problem are outlined.

Keywords: future managers; innovations; professional culture; professional culture.

П остановка проблеми. Складні політичні та соціально-економічні детермінанти розвитку сучасного українського суспільства актуалізують проблему трансформації сутності процесу професійної підготовки майбутніх менеджерів на ціннісних орієнтирах. В умовах сьогодення паралельно зростають вимоги до професійних якостей майбутніх управлінців, як суб'єктів найбільш чисельної складової сфери послуг. Зростання інтересу громадськості до професійної підготовки майбутніх менеджерів обумовлено передусім тим, що домінуючу позицію уїх майбутній діяльності відіграє людський фактор. Діяльність фахівця у галузі управління повинна грунтуватися на аксіологічних, акмеологічних, гуманістичних та демократичних засадах, чітко виражати професійну позицію $\mathrm{i}$ протистояти девальвації суспільних цінностей. 


\section{СУТНІСНІ ХАРАКТЕРИСТИКИ ПРОЦЕСУ ФОРМУВАННЯ КУЛЬТУРИПРОФЕСІЙНӦ̈ ДІЯЛЬНОСТІ МАЙБУТНІХ МЕНЕДЖЕРІВ}

Проблемі процесу формування культури професійної діяльності майбутніх менеджерів присвячені праці багатьох науковців, зокрема таким iï аспектам: теоретико-методологічні засади підготовки майбутніх фахівців у навчальновиховній діяльностізакладувищої освіти (С. Архипова, I. Бех, С. Вітвицька, Н. Ничкало, В. Стрельніков, М. Фіцула та ін.); вивчення нових цілей, принципів і методологічних підходів у освітньому процесі закладу вищої освіти (Е. Волков, К. АльбухановаСтавська, А. Брушлинський, В. Татенко, В. Андреєва, Г. Ващенко, В. Гриньов та ін.); формування професійної культури майбутніх менеджерів (Л. Батченко, О. Виговська, М. Гриньова, М. Дробноход, М. Захаров, В. Жигірь, Л. Каращук, Н. Коломинський, О. Крупський, С. Крисюк, С. Намлієв, Р. Шакуров та ін.).

Мета статті полягає у висвітленні сутнісних характеристик процесу формування професійної культури майбутніх менеджерів.

Виклад основного матеріалу. Професійна культура є продуктом діяльності людей, зайнятих у певній сфері діяльності. Вона включає в себе комплекс знань, умінь і навичок, якими повинен володіти і керуватися у своїй діяльності кожен член суспільства, незважаючи на його професійну приналежність. Вона являє собою сукупність базових професійних знань, умінь і навичок, готовності до побудови й вирішення інноваційних завдань, досвіду практичної діяльності, нелінійного мислення, а також стійкого володіння інформаційними технологіями [1].

Термін “професійна культура" підкреслює, що культура розглядається як специфічна якість діяльності фахівця та розкриває предметний зміст культури, який визначається специфікою професії, професійної діяльності та професійного співтовариства [6].

Професійну культуру менеджера слід розглядати як високий рівень професіоналізму людини, як спосіб творчої самореалізації в професійній діяльності, як процес освоєння, передачі професійних цінностей, становлення системи особистісних сенсів, які розглядаються як ступінь якості професійної діяльності та життя людини [6].

Зазначимо, що міст і структура професійної культури менеджера є складовою його загальної культури та професійних компетентностей, що виступає складним ціннісним утворенням, яке характеризується не лише особистою, духовною і матеріальними культурами, але й задоволенням в управлінській праці, знаннями в галузі економіки, психології, менеджменту тощо [2].

Якість освітнього процесу в умовах закладу вищої освіти визначається не тільки обсягом засвоєного майбутнім фахівцем змісту знань, умінь і навичок професійної діяльності, але й усвідомленням норм, правил, моделі професійної поведінки менеджера, сформованістю професійного кредо; ідентифікацією з професією, бажанням та вмінням постійно самовдосконалюватися. Відтак, мова йде про необхідність посиленої уваги до процесу формування професійної “Я-концепції” майбутнього менеджера, що включає усвідомлення себе як професіонала, носія професійної культури, представника певної професії. Особливості продуктивної Я-концепції зумовлені особливостями етапу професійного становлення й особливостями професійної діяльності [3].

Слід зауважити, що важливим при цьому $є$ мотивація розвитку “образу Я”, яка формується як в умовах як аудиторної (вивчення комплексу таких дисциплін, як от: “Основи підприємницької діяльності”, “Основи менеджменту”, "Управління”, “Стратегічне управління”, “Цілеорієнтовна мотивація”, “Управлінський облік”, “Управління якістю”, “Теорія організаціі”, “Концепції та моделі міжнародного менеджменту”, “Антикризовий менеджмент”, “Стратегічний менеджмент”, “Міжнародний менеджмент”, “Менеджмент персоналу”, “Кадровий менеджмент”, “Ділова етика”, “Адміністративний менеджмент”, “Інноваційний менеджмент”, “Бізнес-планування”, “Основи управлінського консультування”, “Корпоративне управління”, “Менеджмент організацій”, “Самоменеджмент”, “Менеджмент”, “Професійна культура менеджера”, “Маркетинг персоналу”, “Акмеологічний тренінг”, “Організація праці менеджера”, “Публічне адміністрування”, “Операційний менеджмент”, “Технології управління персоналом”, “Управління персоналом”, що дозволяють сформувати професійну культуру майбутніх менеджерів через поєднанні матеріалу професійної спрямованості з проблематикою про культурні цінності, що в підсумку формує світоглядну концепцію спеціаліста, закладає основи фахового та логіко-інформаційного мислення, накопичує необхідні знання, виробляє професійні навички та вміння). Так i позааудиторної діяльності (екскурсії на кращі підприємства туристської сфери, когнітивні тренінги, рефлексивні тренінги, написання мінітворів, само- і взаємооцінки, дискусії, круглі столи за участю фахівців-практиків, занурення в професійні ситуації, моделювання професійних ситуацій, ділові і рольові ігри, рольові тренінги, складання життєвих і професійних планів і перспектив, стратегій професійного розвитку, професійні практикуми, квести, флеш-моби, ділові 


\section{СУТНІСНІ ХАРАКТЕРИСТИКИПРОЦЕСУ ФОРМУВАННЯ КУЛЬТУРИПРОФЕСІЙНОЇ ДІЯЛЬНОСТІ МАЙБУТНІХ МЕНЕДЖЕРІВ}

ігри, брейн-ринги, кейси, психологічні тренінги, індивідуальні консультації, виконання контрольних робіт, ситуаційні методи, майстер-класи, вебінари, воркшопи, робота клубів, гуртків, секцій, науковопрактичних конференцій, ділові ігри, SWOT-аналіз та ін.).

Не менш важливими заходами, що також мають на меті формування культури професійної діяльності майбутніх менеджерів є міжнародний обмін досвідом, що можна побачити на прикладі програм стажувань для студентів від компанії Unilever, як от: “Unilever Internship program" (ULIP), щорозроблена спеціально для студентів 5 - 6 курсів й надає можливість протягом трьох місяців (двічі на рік) проходити стажування в різних департаментах компанії: маркетингу, продажах, логістиці, фінансах, корпоративних комунікаціях, управлінні персоналом та ін. Можлива також участь майбутніх фахівців у програмі обміну "Unilever Future leaders program" (UFLP)”, що розроблена для старшокурсників та випускників закладів вищої освіти, яка розрахована на 2,5 роки й дозволяє студентам стати безпосередніми учасниками в роботі над бізнеспроектами на позиції молодшого менеджера й дозволить отримати багатосторонній досвід міжнародного стажування в одному $з$ офісів Unilever за кордоном.

Існують такі компоненти професійної культури майбутнього менеджера: пізнавальний, мотиваційно-емоційний, діяльнісний та регулятивний. Пізнавальний компонент передбачає відповідність навчальних i професійних інтересів педагога, стійку потребу у самоосвіті, володінні інформацією про зміст інноваційних технологій та безпосередньо 3 предмета, що він викладає. Мотиваційноемоційний компонент - це позитивне ставлення до педагогічної діяльності, задоволення становищем у соціально-професійній групі. Діяльнісний компонент - відповідність знань, умінь, навичок та їхня реалізація під час навчання, застосування знань про управлінську та проектну діяльність. Регулятивний компонент формування суб'єктивної педагогічної позиції, сформованість особистісного культурного "Я"; рефлексія як особистісне новоутворення студента; самовдосконалення, а саме: конференції, симпозіуми, семінари, тренінги тощо; уміння вдосконалювати професійно значущі якості. Перелічені компоненти дають можливість встановити такі рівні сформованості професійної культури майбутніх менеджерів: високий, середній, низький. Високий рівень передбачає чітке уявлення про сформованість своєї професійної культури, власний розвиток особистості; професійну компетентність, володіння спеціальними знаннями й уміннями; самостійний пошук рішення педагогічних проблем; самоаналіз і самовдосконалення. Середній і низький рівні характеризуються відсутністю бажання до саморозвитку, підвищення власного рівня знань $і$ умінь [4].

У майбутніх менеджерів, що готуються проходити практику, відповідно до усіх вимог, формується готовність до освоєння засад майбутньої професійної діяльності; створюється можливість апробувати спеціальні теоретичні знання у безпосередній практичній діяльності; оволодіти певними професійними нормами, традиціями притаманними професії “менеджер”; виробити власний стиль професійної діяльності тощо.

Як зазначає Л. Марченко, у практику професійної підготовки менеджерів слід впроваджувати інновації, що мають вигляд певної моделі інноваційного освітнього процесу, яка охоплює шість етапів: 1) виявлення потреби у нововведенні (виявлення й аналіз проблеми, усвідомлення потреби у нововведенні, переконання суб'єктів організації в необхідності нововведення); 2) збір інформації про можливі нововведення, які забезпечать розв'язання проблеми (пошук інформації щодо способів розв'язання подібних проблем, виявлення варіантів інноваційних рішень); 3) оцінювання інноваційних проектів за критеріями здійснення й освітньої доцільності (розроблення інноваційних проектів, оцінювання прогнозних результатів впровадження кожного проекту, вибір інноваційного проекту); 4) прийняття рішення про впровадження інновації (рішення про доцільність впровадження відібраного інноваційного проекту, ухвалення рішення вищим керівництвом); 5 ) впровадження нововведення (пробне впровадження, повне впровадження, використання); 6) інституціоналізація нововведення (рутинізація, модифікація, дифузія) [5, 250].

Суттєвими ознаками професійної культури майбутнього управлінця слід вважати: творчий підхід до вирішення на практиці ситуаційних завдань і проблемних ситуацій та готовність до взаємодії з іншою стороною з метою спрямування зусиль на досягнення спільних цілей, наявність інформаційної культури підприємницької діяльності та широкої ерудиції щодо питань модернізації сучасних управлінських рішень на шляху до міжнародної інтеграції в контексті загальнолюдських цінностей та культурних традицій. Відтак, професійну культуру майбутнього менеджера 
доцільно розглядати у контексті таких ï складових, як от: професійний світогляд (знання; соціальний досвід; погляди на управління у сфері туризму); професійна поведінка як ціннісний прояв особистості; професійна майстерність, яка проявляється у вмінні поєднувати способи, методи та засоби управління, включаючи власний комплекс умінь та навичок управлінця.

Висновки. Отже, узагальнюючи вищевикладене, можна зробити висновок, що органічне поєднання в освітньому процесі закладу вищої освіти різних форм аудиторної та позааудиторної діяльності виступають найважливішими чинниками формування професійної культури майбутніх менеджерів. Водночас, професійна культура майбутніх менеджерів має формуватися у систематичному підвищенні кваліфікації, творчій активності, здатності продуктивно задовольняти зростаючі вимоги освіти та суспільства.

Перспективи подальших наукових розвідок полягають у вивченні зовнішніх та внутрішніх чинників, що мають значний влив на процес формування культури професійної діяльності майбутніх менеджерів в умовах закладу вищої освіти.

\section{ЛІТЕРАТУРА}

1. Алексюк А. Педагогіка вищої освіти України. Історія. Теорія : підручник. Київ, 1998. $560 \mathrm{c}$.

2. Алімасова Д. Підготовка майбутніх менеджерів до використання нових інформаційних технологій у професійній діяльності: автореф. дис. ... канд. пед. наук: 13.00.04. Ялта, 2014. 20 с.

3. Гриньов С. Технологія формування професійної культури майбутнього менеджера для нової української школи. Витоки педагогічної майстерності. 2019. Випуск 23. С. 54-58.

4. Загнибіда Р. Особливості формування професійної культури майбутніх менеджерів туризму. Вісник Черкаського університету. Вип. № 6. 2017. Серія “Педагогічні науки”, С. 67-71.

5. Марченко Л. Управління інноваційною діяльністю педагогів в умовах профільних загальноосвітніх навчальних закладів. Збірник наукових праць Бердянського державного педагогічного університету : педагогічні науки. Бердянськ. 2009. № 2. С. 248-250.

6. Романовський О. Шляхи впровадження інновацій, підприємництва та підприємницької освіти в системі національної освіти України: Монографія. Вінниця, 2010.416 с.

\section{REFERENCES}

1. Aleksiuk, A. (1998). Pedahohika vyshchoi osvity Ukrainy. Istoriia. Teoriia [Pedagogy of Higher Education of Ukraine. History. Theory: a textbook]. Kyiv, 560 p.[in Ukrainian].

2. Alimasova, D. (2014). Pidhotovka maibutnikh menedzheriv do vykorystannia novykh informatsiinykh tekhnolohii u profesiinii diialnosti [Preparing future managers for the use of new information technologies in their professional activities]. Extended abstract of candidate's thesis. Yalta, 20 p.[in Ukrainian].

3. Hrynov, S. (2019). Tekhnolohiia formuvannia profesiinoi kultury maibutnoho menedzhera dlia novoi ukrainskoi shkoly [Technology of formation of professional culture of the future manager for the new Ukrainian school]. The origins of pedagogical skills, No. 23, pp.54-58. [in Ukrainian].

4. Zahnybida, R. (2017). Osoblyvosti formuvannia profesiinoi kultury maibutnikh menedzheriv turyzmu [Features of formation of professional culture of future tourism managers]. Bulletin of Cherkasy University. Vol. 6. "Pedagogical Sciences" Series, pp. 67-71. [in Ukrainian].

5. Marchenko, L. (2009). Upravlinnia innovatsiinoiu diialnistiu pedahohiv $\mathrm{v}$ umovakh profilnykh zahalnoosvitnikh navchalnykh zakladiv [Management of innovative activity of teachers in the conditions of specialized general educational institutions]. Collection of scientific works of Berdyansk State Pedagogical University: pedagogical sciences. Berdiansk, No.2, pp.248-250. [in Ukrainian].

6. Romanovskyi, O. (2010). Shliakhy vprovadzhennia innovatsii, pidpryiemnytstva ta pidpryiemnytskoi osvity $v$ systemi natsionalnoi osvity Ukrainy: Monohrafiia [Ways of introducing innovation, entrepreneurship and entrepreneurship education in Ukraine's national education system: Monograph]. Vinnytsia, 416 p. [in Ukrainian].

Стаття надійшла до редакції 05.11.2019

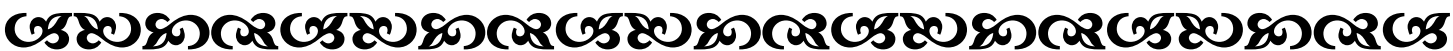

"Лрацюй, коли тобі сумно, - це єдиний засіб розігнати смуток. Лрацюй, коли тобі супроводжує успіх: немає інших ліків проти “запоморочення”, оқрім роботи”.

\section{O58080ल2058080}

